\title{
A Logical-Mathematical Approach for the Implementation of Ecologically Equipped Productive Urban Areas
}

\author{
Maria Rosaria Sessa *(D), Benedetta Esposito (D), Daniela Sica (D) and Ornella Malandrino \\ Department of Business Studies Management and Innovation Systems, University of Salerno, 84084 Salerno, Italy; \\ besposito@unisa.it (B.E.); dsica@unisa.it (D.S.); ornellam@unisa.it (O.M.) \\ * Correspondence: masessa@unisa.it
}

check for updates

Citation: Sessa, M.R.; Esposito, B.; Sica, D.; Malandrino, O. A

Logical-Mathematical Approach for the Implementation of Ecologically Equipped Productive Urban Areas. Sustainability 2021, 13, 1365.

https://doi.org/10.3390/su13031365

Academic Editor: Maria

Rosaria Guarini

Received: 28 December 2020

Accepted: 23 January 2021

Published: 28 January 2021

Publisher's Note: MDPI stays neutral with regard to jurisdictional claims in published maps and institutional affiliations.

Copyright: (c) 2021 by the authors. Licensee MDPI, Basel, Switzerland. This article is an open access article distributed under the terms and conditions of the Creative Commons Attribution (CC BY) license (https:/ / creativecommons.org/licenses/by/ $4.0 /)$.

\begin{abstract}
Sustainability is a complex phenomenon that refers to economic, environmental, and social aspects. Any concept of sustainable urban development must incorporate sectoral concepts; these must be well integrated into the overarching urban, regional, and governance policies. One sectoral policy of great importance is the redevelopment processes of disused industrial areas into Sustainable Industrial Areas (AIS), Ecologically Equipped Productive Areas (APEA), or Eco-Industrial Parks (EIP). These territories, as socioeconomic systems that are being observed in the framework of the development of sustainability monitoring, are complex objects for evaluation due to the presence of a large number of interconnections between the constituent elements and hierarchical levels (sectors and spheres). For this reason, it is necessary that a new interpretation of economical, natural, and social phenomena, following a systemic and integrated approach, is able to reinterpret them for the dissemination of an ecologically and socially sustainable economy. The purpose of this work is to analyse the state of realisation of APEA on the Italian national territory, in order to understand the real benefits of production areas managed through eco-efficiency standards and to guarantee an integrated management system of environmental aspects. An additional aim is to consider a logical-mathematical model that would be able to support territorial policies in the identification of suitable areas to be converted into APEA, in order to promote sustainable development of the territory.
\end{abstract}

Keywords: APEA; disused industrial areas; logical-mathematical approach; sustainable development

\section{Introduction}

The development of a territory, whether already highly urbanized and/or in a phase of progressive urban growth, tends to meet both the needs of the population and of private subjects. To adequately satisfy these needs, the actions implemented in the territory have to produce multiple effects over time, such as significant change in the balance between the natural environmental system and the economic social system [1].

Within this scenario, there is a need to develop a new key to understanding of the phenomena that regulate territorial growth. This promotes a systemic approach based on the principles of an ecologically and socially sustainable economy [2-4].

The implementation of sustainable managerial practices for the redevelopment of disused industrial areas into Sustainable Industrial Areas (SIA) presupposes the need to reformulate the traditional economic productive system of the reference territory. Moreover, the use of accurate assessment procedures is needed that are attentive to the detection of the effects that these practices produce. This is important at both the international-for the global dimension of some phenomena-and at the regional and local regional scale, due to the urgency of identifying production and consumption models that can reconcile economic development with the protection of the natural environment into different sociocultural contexts. [5].

In the first decades of the 21st century, the topic of environmental protection has been increasingly at the centre of discussion at both European and international levels, 
concerning the identification of new management logics existing and/or newly formed businesses according to sustainability principles [6-8].

This is because environmental resources are increasingly seen, in synergy with other factors - such as the globalization of markets, technological innovation, and social equityas a useful tool for the development of sustainable forms of economy. Nowadays, the Circular Economy is the model that better supports the implementation of sustainable principles. In fact, the Circular Economy has been gaining traction as an approach for achieving local, national, and global sustainability. Eco-design, repair, reuse, refurbishment, remanufacture, product sharing, waste prevention, and waste recycling are all important in a Circular Economy [9].

The Circular Economy is thereby defined through specific actions and practices. Circular Economy practices are important elements for the transformation to systems of sustainable consumption and production [10]. The academic literature and relevant reports suggest that the Circular Economy model could bring important benefits of cost savings, job creation, innovation, productivity, and resource efficiency in both developed and developing countries [11-14]. Problems related to the assessment of environmental impacts, which may arise from local and non-local production activities, are introduced to research and define new procedures and eco-friendly policies.

Since 2007, in Europe the objective has been set of integrating the principles of sustainability in the localization, establishment, and management of industrial production areas in a state of complete and/or partial abandon.

For this reason, it is very important to consider the sustainability objectives recently illustrated in Agenda 2030 (2015) of the United Nations (UN). Through this Programme, member countries undertake actions to respect and consider the sustainable principles in the planning and implementation of intervention policies in urban industrial territories. Possible urban sustainable actions include the transformation processes of disused industrial areas carried out according to the resettlement model of the Eco-Industrial Parks (EIP) $[15,16]$.

In Italy, the EIP are equivalent to the term of Sustainable Industrial Area (SIA) that takes on different terminology variations: Ecologically Equipped Productive Area (Italian acronym: APEA), Ecologically and Socially Equipped Productive Area (Italian acronym: APSEA), or Ecologically Equipped Area (Italian acronym: AEA), [17].

In Italy, the Act n.59 in March 1997 and the Legislative Decree n.11 in March 1998 (Bassanini Decree) considered APEA the possible tool to integrate economic capital with natural and social aspects of management of the territory. According to these laws, Regions and local institutions have the mission to identify the specific areas allocated to APEA and to ensure implementation of methods through the realisation of adept guidelines [18]. Specifically, the decision to transform specific portions of the territory according to the APEA model must be based on appropriate targets, which concern the possibility of providing a recreational space for residents (Recreational targets) in respect of the morphological natural characteristics of the area (Environmental targets) and of the productive vocation of the area to be redeveloped (Structure-Strengthening targets) [19]. Considering the type of target to be achieved, it is possible to use appropriate performance indicators to express and measure: the environmental aspects and the degree of usability of the soil within the production area to be redeveloped (for example, not exhaustive, \% types of land use, square meters of land used as green areas, the annual average concentration of the main pollutants in the atmosphere); the level of infrastructure of the reference urban context (for example, not exhaustive, square meters of parking areas, $\mathrm{km}$ of cycle paths, number of bus stops); the socioeconomic characteristics that characterize the industrial area (for example, not exhaustive, number of employees, number of companies from the production sector, $\mathrm{ROI}$ of the production sectors characterizing the economic productive system of the area to be redeveloped) [20].

In light view of these premises, the work aims to analyse the state of realisation of APEA on national territory, in recent years, in order to understand the real benefits of the 
production areas managed through eco-efficiency standards and to guarantee an integrated management system of environmental aspects: from decrease and prevention of air, water, and soil pollution to the protection of health and safety of individuals. In this context, the proposal of a multi-criteria economic analysis model [21-24] can support the territorial policies of public bodies in identifying the areas that are best suited to be converted into APEA based on considerations not only of a financial nature but also of a social, cultural, and environmental nature.

In particular, this model can help to promote: the redevelopment of disused areas of industrial origin, the improvement of the architectural and landscape quality of the existing and/or disused production area, the increase of the qualitative standards of the productive environment in support of a high-level innovative activity (in terms of specificity of production and the reduction of environmental impact).

\section{Materials}

The growing attention on the environmental sustainability of products and production processes, the expansion of markets in a global dimension, the growing desire of consumers to buy in the short term, the effects of climate change on territorial balance and human health because of pollution phenomena, the importance of using criteria of social equity in the distribution of wealth, and the protection of human rights led to the transformation of the current global production system. Therefore, in recent years, interest in industrial areas and again, following principles of sustainability, the production systems that reside within them and the territory in which they are located has been growing.

In the Declaration of Toledo (2010), the European Ministers for regional development, in light of the principles of sustainability, defined the territory as a complex system, comprising not only urbanized, rural, and other spaces, e.g., industrial land, but nature as a whole and the environment surrounding mankind; therefore, a holistic multidisciplinary approach should be adopted, capable of harmonizing the various of variables, economic, environmental, and social sustainability locally. In contrast, production systems can be understood as a set of many interdependent and different elements. These have the objective to transform input resources into output finished products. This definition of the production system fits into a larger context, which is the industrial area defined as the territory in which they are located in order to achieve economies of scale due to common services and infrastructure [25].

Internationally, the sustainability of a territory is defined using the concept of EcoIndustrial Parks (EIPs), within which mutually beneficial relationships are established between organizations and their environment, through the management of raw materials, by-products, and waste shared as indicated by the principles of industrial ecology [26]. The approach is based on the brand-new Circular Economy model, which replaces the typical linear chains of conventional industry in industrial systems-closed-loop-and resembles the ecological systems in which there is no waste, but only products which are reused or recycled. To date, there is no unambiguous definition shared for the same concept [27]. Different terminologies and definitions are used by various organizations around the world to refer to EIPs or relatively similar concepts.

Figure 1 presents the various combinations of commonly used terminologies that directly or indirectly relate to the concept and practice of sustainable production areas. This publication does not aim to dictate terminology. Rather, it highlights areas of alignment that provide a practical way to move forward regardless of whatever terminology is being used.

The idea of Eco-Industrial Parks was first described during a presentation at the United Nations Conference on Environment and Development (UNCED) in Rio de Janeiro in 1992. By early 2005, communities in Africa, Asia, Europe, South America, and the United States had initiated EIP or other eco-industrial development planning processes. For many, EIPs were viewed as an appropriate and effective framework to transition to sustainable production. As a result, Eco-Industrial Parks became commonly used as a reference term. 
The EIP concept and approach have evolved to address additional, interrelated aspects, including, for example, resource efficiency and cleaner production, industrial symbiosis, climate change, pollution, social standards, shared infrastructure, improved spatial zoning, and management [28].
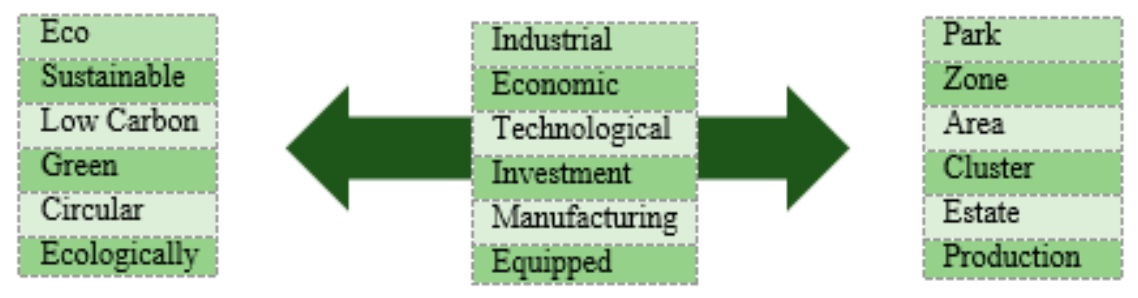

Figure 1. Examples of combinations of terminologies used internationally in relation to sustainable production areas.

One of the most accredited definitions of EIP is given by Lowe and Moran (1995), for which the eco-industrial parks can be understood as a community of manufacturing and service businesses located together on common property. Member businesses seek enhanced environmental, economic, and social performance through collaboration in managing environmental and resource issues. By working together, the community of businesses seek a collective benefit that is greater than the sum of benefits each company would realize by only optimizing its individual performance [29].

One of the most significant drivers of EIPs is the opportunity to increase business, industrial competitiveness, and sustainable growth. Support for the development of EIPs can be offered through the provision of economically, environmentally, and socially aligned services and a plan to meet the sustainability agenda for an industrial area. In particular, it is possible to identify key environmental, economic, and social drivers of EIPs (see Table 1).

Reaching these targets will require deep and long-lasting changes by organizations in different industrial sectors. Therefore, in this context, EIPs have the potential to play an important role.

A few years later, Lowe (1997) [30] has, again, expanded the concept of EIPs, by assuming the existence of different types of EIPs: Eco-Industrial Parks or Estates, or parks developed and managed by a single entity to obtain high economic and social benefits, and environmental expertise; By-product Exchange, grouping the organizations aimed at the implementation of the principles of industrial ecology, which promote the exchange of waste to reduce resource consumption and pollution; Eco-Industrial networks, understood as groups of enterprises located in the same territory and oriented to the satisfaction of all the principles of sustainability in order to improve the economic, social, and environmental performance of all players present in the same territory-in this case, companies are not necessarily grouped as an industrial park.

The most typical example of the application of principles of sustainability into a productive industrial area is the park in Kalundborg, Denmark [31,32], the first to have spontaneously created networks and trade flows of materials and energy to reduce costs by reusing waste products as raw materials for other processes.

However, it is interesting to note that nationally, an industrially developed area could be configured differently on the territory. You can also refer to two specific patterns when analysing an industrialized area: industrial districts and sustainable productive areas. Most of the time, both are defined similarly, or as aggregates of production realities, not specifying that the aggregation concerning sustainability requires the development of policies and practices different than the traditional way of managing an industrial district. In fact, it is possible to have a district every time that several undertakings belonging to the same industry or producers of the same product are located on a relatively small territory, in order to determine a series of processes of exchange of raw materials, ideas, and knowledge between them [33]. The district so defined is more of a territorial productive model. That territory, due to its historical, geographical, cultural, and administrative role, 
becomes the connective tissue of relationships between businesses and enterprises and the local community. In contrast, the concept of a Sustainable Productive Area refers to a set of enterprises that do not necessarily need to be of the same production sector. In fact, the objective of the area is to obtain high environmental and social performance through a unified management system. Sustainable productive areas can be considered as an evolution of industrial districts and could support the process of revitalization of the numerous Italian industrial districts, today characterized by a great crisis that could lead to increased risk of disappearance of the same.

Table 1. Main key drivers of Eco-Industrial Parks (EIPs).

\begin{tabular}{|c|c|c|}
\hline Economic & Environmental & Social \\
\hline Direct and indirect employment creation & $\begin{array}{l}\text { Climate change commitments at global } \\
\text { and national levels }\end{array}$ & Better working and labour conditions \\
\hline Skills upgrading of the labour force & $\begin{array}{l}\text { Increased demand to improve efficiency } \\
\text { and growth }\end{array}$ & Transition to more sustainable land use \\
\hline \multirow{2}{*}{$\begin{array}{l}\text { Technology and knowledge transfer } \\
\text { through foreign direct investment }\end{array}$} & $\begin{array}{l}\text { Responding to environmental and social } \\
\text { concerns from consumers }\end{array}$ & Improved occupational health and safety \\
\hline & $\begin{array}{l}\text { Ensuring infrastructure is resilient to } \\
\text { higher resource costs and adapts to } \\
\text { climate change risks }\end{array}$ & Provision of vocational training \\
\hline \multirow{2}{*}{$\begin{array}{l}\text { Linkages between the industrial park } \\
\text { firms and small and medium sized } \\
\text { enterprises (SMEs) and communities } \\
\text { outside the industrial park }\end{array}$} & \multirow{2}{*}{$\begin{array}{l}\text { Greening the supply chain and } \\
\text { alleviating resource constraints, which } \\
\text { can lead to improved resource } \\
\text { management and resource conservation }\end{array}$} & $\begin{array}{l}\text { Support to local community well-being } \\
\text { and community outreach }\end{array}$ \\
\hline & & $\begin{array}{l}\text { Provision of social infrastructure to } \\
\text { workers and community }\end{array}$ \\
\hline \multirow{3}{*}{$\begin{array}{l}\text { Demonstration effects arising from the } \\
\text { application of good international } \\
\text { industry practices and regional } \\
\text { development approaches }\end{array}$} & \multirow{3}{*}{$\begin{array}{l}\text { The presence of relevant policy } \\
\text { mechanisms (for example, taxes and } \\
\text { market mechanisms, such as } \\
\text { carbon pricing) }\end{array}$} & Improvement of gender equality \\
\hline & & Creation of local jobs \\
\hline & & Better security and crime prevention \\
\hline
\end{tabular}

Then, to implement the principles of sustainability in a production area means not only to improve the environmental performance of each production sector but, rather, to implement harmonious sustainable development in the municipality of productive activities and the territory, whereby the strategic objectives of single unit production must be coincident with those of other units belonging to the same area. In fact, for sustainable economic development, a production area needs to focus not only on technological and managerial innovations aimed at maximizing profits and optimization of production efficiency, but also, on improving environmental performance and enhancement of human resources. This implies a greater willingness of the business community to cooperate with the other actors, both public and private, in the area to improve the governance of the territory.

In this regard, the ISPRA Report (2015) [34] emphasized the presence of the best governance practices territory in the national context. The cooperation of different actors in the territory and the adoption of eco-friendly instruments and policies can bring many economic, social, and environmental benefits to the entire community, such as in Figure 2.

This means that creating synergy between companies through joint management processes and/or exchange of raw materials and energy can lead to economies of scale, to an increase in the potential for innovation, to a reduction in environmental impacts, and to an increase in their competitive advantage.

Nevertheless, organizations are not always able to take advantage of the opportunities arising from a system of territorial sustainable production, for which government support is required to create a territorial system that is able to maximize positive externalities and minimize negative externalities such as environmental impacts. 


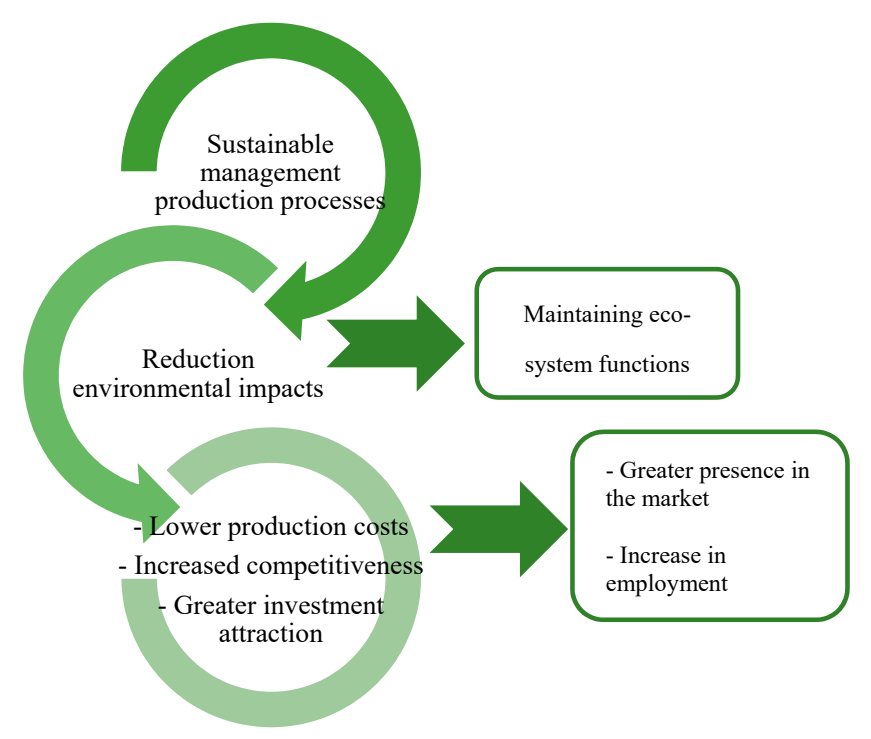

Figure 2. Main benefits of eco-sustainable management.

In this respect, the territorial self-sustainability model [34] (Figure 3) can be referred to, in order to create a win-win strategy; that is, a territory from which all participants in the system, both in the private and public sectors, receive benefits. These are mainly financial benefits. These can be increased only if environmental and social aspects are also recognised and managed. This approach is in line with the concept of Circular Economy. According to this model of economy, a productive system must follow the principle of the 3Rs (reduce, reuse, recycle) [35]. As such, it is possible to minimize environmental impacts and major accidents. Moreover, it is possible to promote the conservation of ecosystem functions in the long term, environmental protection, and the development of the territory.

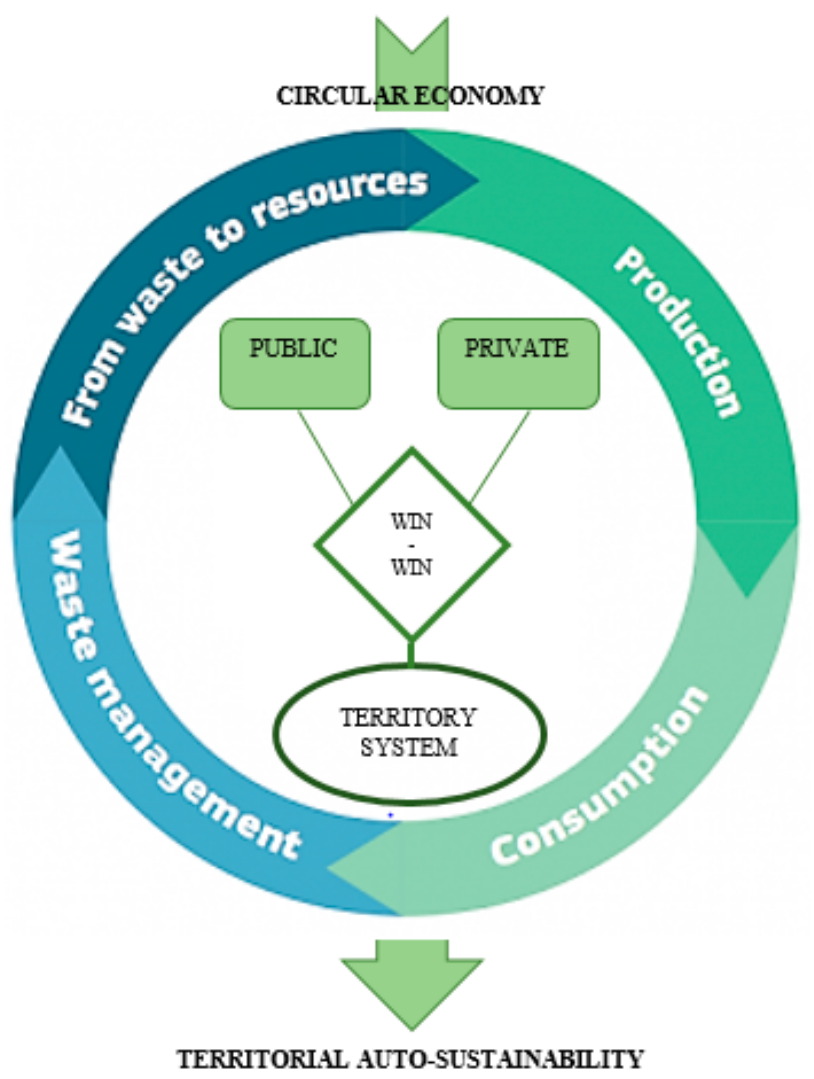

Figure 3. Territory System according to Circular Economy Model. 
EIPs as well as sustainable productive areas, particularly Ecologically Equipped Productive Areas (APEA) in the national context, represent the management structures and governance of the territory which are the closest to the concept of a land system, in order to receive the benefits outlined above.

\section{Productive Area Ecologically Equipped: Italian Response}

For a long time, Industrial Areas (IAs) have been a source of benefits and conflicts for the local population due to their proximity to cities and the related environmental, social, and economic impacts. For this reason, these areas became the places to apply sustainable development principles and tools. IAs are relevant to both local territorial planning and managing and for the possibility to share infrastructures, services, and technologies, while reducing costs and creating synergies among companies in the area. There are many examples of IAs where elements of environmental and social improvements have been applied. These experiences are often called different names such as EIPs, Ecologic Equipped Areas, etc.; despite there still being no common standards, they are a good starting point for IAs enhancement.

In particular, according to the Sustainable Development Report (2020) [36], containing the SDG (Sustainable Development Goals) Index and dashboard, Italy ranks 30th out of 162 UN member countries, with respect to the levels of sustainability achieved on its territory. Italy's main critical issues concern the SDGs 9 (Industry, innovation and infrastructure), 12 (Responsible consumption and production), 13 (Climate action), and 14 (Life under water), while the situation is concretely better in Goals 3 (Health and well-being), 6 (Clean water and sanitation), 7 (Clean and accessible energy), 15 (Life on earth), and 16 (Peace, justice and strong institutions).

In this regard, the process of localising the 2030 Agenda is essential to make its guidelines effective according to the specificities of individual territories. The universal nature of the 17 Sustainable Development Goals does not preclude the priority need to contextualise their content at the territorial level; rather, it recognises the peculiarities of very different local situations.

Precisely for this, therefore, the implementation of the Agenda at the territorial level is based on the specific characteristics and specific needs of the different territories [37] and by formulating, implementing, and monitoring of ad hoc strategies.

In this sense, global development that is not tailored to individual realities is insufficient to achieve the desired paradigm shift [38]. Instead, local governments and urban and rural communities play a crucial role in achieving the SDGs and in overcoming obstacles at the local level, concerning the management of economic, environmental, and social aspects [39].

It is in this scenario that the APEA concept is placed, as a tool able to reconcile economic development with protection of the environment and the social growth of the territory of productive areas in crisis.

In Italy, an efficient management model of a productive system could be APEA. This model would allow the development of specific territory systems and a lot of benefits as shown in previous paragraph.

The APEA model in the national context corresponds to EIPs in the international context, though there are significant differences. One of them is that APEA is not an agreement between enterprises for commercial aims but to manage environmental and social aspects by united governance and planning. This implicates strong collaboration between the public and private sector.

These structures have been introduced in Italy by Act n.59 in March 1997 and the Legislative Decree n.11 in March 1998 (Bassanini Decree) considered APEA the possible tool to integrate economic capital with natural and social capital of the territory; according to these laws, the Regions and the local institutions have the mission to identify the areas allocated to APEA and to enforce implementation methods through the realisation of adept 
guidelines. In particular, single Regions have the mission to discipline the matter, taking into consideration some elements in common:

(1) Ecologically Equipped Areas have infrastructures and the system necessary to guarantee health, security, and environmental protection;

(2) Ecologically Equipped Areas are characterized by unitary management of infrastructures and services;

(3) The same laws discipline unitary management of infrastructures and services of Ecologically Equipped Areas from public or private subjects, as well as land purchase belonging to industrial areas;

(4) In many cases, it can be tax breaks and public funding.

Nowadays, according to the latest feasibility studies in the context of Project FSE 2007-2013 (2012) [5], Regions that have legislated in the field of APEA or similar topics are listed in Table 2.

Table 2. Regions that have legislated on the topic of Ecologically Equipped Productive Areas (APEA) or related topics.

\begin{tabular}{|c|c|c|c|c|}
\hline Region & $\begin{array}{c}\text { Regional Laws Regarding } \\
\text { APEA }\end{array}$ & $\begin{array}{c}\text { Other Deeds Regarding } \\
\text { APEA }\end{array}$ & $\begin{array}{l}\text { Other Deeds, Documents or } \\
\text { Regional Planning Laws }\end{array}$ & Guidelines \\
\hline Abruzzo & $\begin{array}{l}\text { R.L, } 1999 \text { n. } 11(16 ; 22 ; 26 ; 28) \\
\text { R.L., } 2011, \text { n. } 23\end{array}$ & $\begin{array}{l}\text { Resolution R.G., 2003, n. } 1122 \\
\text { Resolution R.G., } 2004 \text { n. } 1252 \\
\text { Resolution R.G., 2012, n. 62/P }\end{array}$ & & \\
\hline Calabria & $\begin{array}{l}\text { R.L., } 2001, \text { n. } 38 \text { (21) } \\
\text { R.L., 2002, n. } 34(33 ; 35) \\
\quad \text { R.L., } 2011, \text { n. } 47\end{array}$ & & & \\
\hline $\begin{array}{l}\text { Emilia } \\
\text { Romagna }\end{array}$ & $\begin{array}{l}\text { R.L., } 1999, \text { n. } 3(49 ; 64) \\
\text { R.L., } 1999, \text { n. } 9 \text { (4) } \\
\text { R.L., 2002, n. } 31(30) \\
\text { R.L., 2004, n. } 26(17)\end{array}$ & $\begin{array}{l}\text { Resolution R.G., 2003, n. } 484 \\
\text { Resolution R.A., 2007, n. } 118 \\
\text { Resolution R.G., 2010, n. } 142\end{array}$ & $\begin{array}{l}\text { R.L, 2000, n. } 20 \text { (A-13;A-14) } \\
\text { Resolution R.G., 2001, n. } 1620 \\
\text { Resolution R.G., 2003, n. } 18\end{array}$ & $\begin{array}{l}\text { Bologna } \\
\text { Provincial } \\
\text { Modena } \\
\text { Provincial }\end{array}$ \\
\hline Liguria & $\begin{array}{l}\text { R.L., } 1998, \text { n. } 14 \text { (3) } \\
\text { R.L., } 1999, \text { n. } 9(9 ; 10)\end{array}$ & $\begin{array}{l}\text { Resolution R.G., 2000, n. } 1486 \\
\text { Resolution R.G., 2002, n. } 92 \\
\text { Resolution R.G., 2003, n. } 648 \\
\text { Resolution R.G., 2003, n. } 814 \\
\text { Resolution R.G., 2004, n. } 835\end{array}$ & $\begin{array}{l}\text { Resolution R.G., 2000, n. } 272 \\
\text { Resolution R.G., 2003, n. } 43\end{array}$ & \\
\hline Marche & $\begin{array}{l}\text { R. L., } 1999, \text { n. } 10(17-19) \\
\text { R. L., 2003, n. } 20(2 ; 10 ; 19) \\
\quad \text { R. L., } 2005 \text { n. } 16(14)\end{array}$ & $\begin{array}{l}\text { Resolution R.G., 2003, n. } 86 \text { (7) } \\
\text { Resolution R.G., 2003, n. } 1433 \\
\text { Resolution R.G., } 2005 \text { n. } 157\end{array}$ & $\begin{array}{l}\quad \text { R.L., 2004, n. } 7 \text { (3) } \\
\text { Resolution R.G., 2004, n. } 1115 \\
\text { Resolution R.G., 2005, n. } 1469\end{array}$ & Marche Region \\
\hline Piedmont & $\begin{array}{l}\text { R. L., 2000, n. } 44 \text { (17;18) } \\
\text { R. L., 2004, n. } 34\end{array}$ & Resolution R.G., 2009, n. 30 & Resolution R.G., 2001, n. 29 & $\begin{array}{l}\text { Piedmont } \\
\text { Region }\end{array}$ \\
\hline Apulia & $\begin{array}{l}\text { R. L., 2000, n. } 24(6) \\
\text { R. L., 2001, n. } 19 \text { (1) } \\
\text { R.L., 2003, n. } 2(1-12) \\
\text { R. L., 2007, n. } 2(5)\end{array}$ & & & \\
\hline Tuscany & R.L., 1998, n. 87 (18) & $\begin{array}{l}\text { Resolution R.G., 2009, n. 74/R } \\
\text { Resolution R.G., 2009, n.1245 }\end{array}$ & $\begin{array}{c}\text { Resolution R.G., 2000, n. } 12 \text { (11) } \\
\text { Resolution R.G., 2000, n. } 283 \\
\text { Resolution R.G., 2002, n. } 24 \\
\text { Resolution R.G, 2004, n. } 109 \\
\text { Resolution R.G., 2004, n. } 1130\end{array}$ & $\begin{array}{l}\text { Tuscany } \\
\text { Region }\end{array}$ \\
\hline Sardinia & R.L., 2008, n. 10 & & & \\
\hline
\end{tabular}

Table developed according to Project FSE 2007-2013, 2012.

Sardinia has recently been added to these; it is interested in the drafting of a Protocol together with other Italian Regions that already know APEA logics, addressed to sustainable management of clusters, local areas, and homogeneous enterprise systems.

Therefore, Regions that have not legislated specific deeds, in most cases, however, have arranged to provide laws or resolutions that refer to the next legislation, or that 
contain general indications to the development of production areas of new generation, or that realise laws or resolutions on relevant topics, such as the constitution and development of industrial associations (Friuli Venezia Giulia). In Lazio Region, for example, a specific law in the field of APEA is the subject of study, while Lombardy has not yet arranged to legislate in this field. Only guidelines at the provincial level have been realised. Finally, other Regions, such as Sicily and Campania, do not have specific laws and have revoked previous instructions in this field. These Regions propose the establishment of a united subject at the regional level for the sustainable management of all productive areas [40].

Italian Regions (Figure 4) that, up to now, have arranged to provide regulations or deeds containing specific indications in the field of APEA are nine Regions (Abruzzo, Emilia Romagna, The Marche, Liguria, Piedmont, Tuscany, Sardinia and two Regions Agreement Goals-Apulia and Calabria).

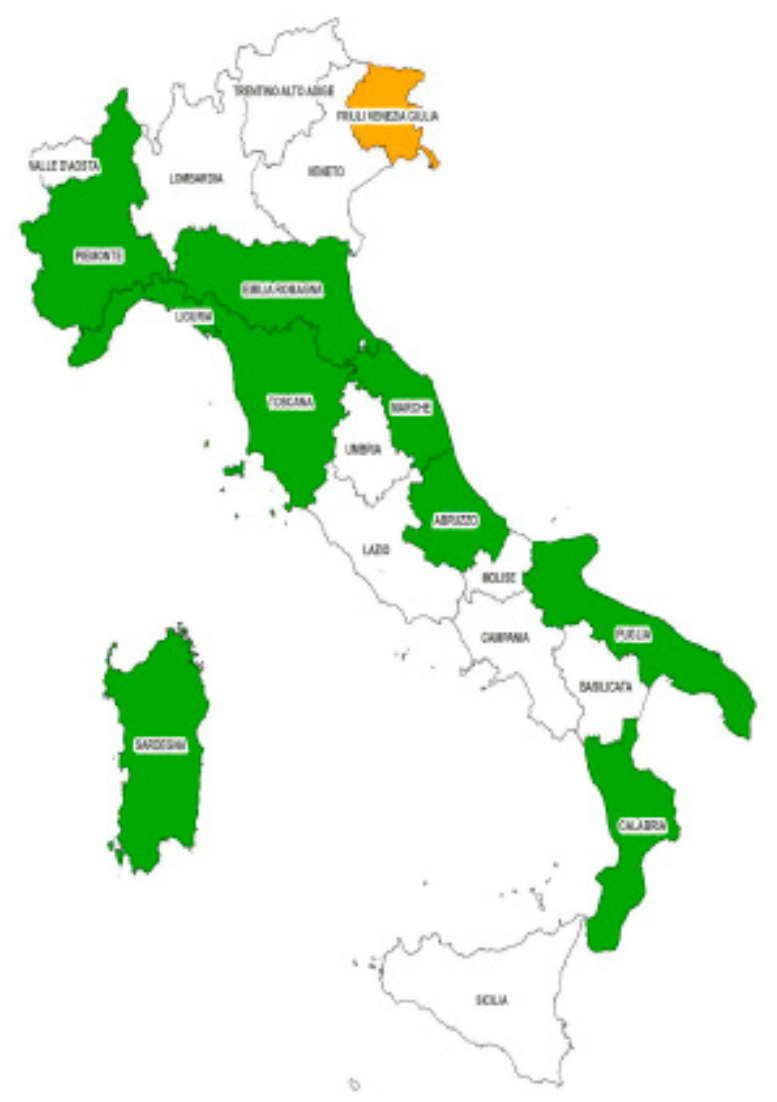

Figure 4. Regions with regulations or deeds showing specific indications regarding APEA. Source: processing data on Project FSE 2007-2013, 2012.

This implies that Regions arrange precise regulations concerning urban aspects, environmental and energetic requisites, and public funding of which APEA can benefit from. Urban indications concern identification, from Municipalities, of Ecologically Equipped Areas, in their own territory, considering limitations of soil consumption and results of economic, urban, local, and landscape surveys.

Regarding environmental and energy aspects, regional laws dictate that the APEA must achieve the goal of eco-efficiency from the point of view of the settlement by relying on two basic elements: the creation of new infrastructure and services to complement existing ones and the organization of production sites to economically and technically help enterprises that individually would not be able to achieve sustainable development goals [41]. However, for forms of financing, the Regions shall determine autonomously how to act in terms of benefits, incentives, and financing. Precisely through the analysis of the provisions, guidelines, and regional deliberations and the existing literature on the 
subject, albeit deficient, it is possible to identify three profiles of ecologically equipped productive areas that are distinguished (Figure 5):

- Newly constructed areas: areas to be carried out on undeveloped land or areas belonging to abandoned settlements; covered areas resulting from unauthorized modification of the existing settlements involving, in part because of urban territorial relevance, an entirely different creation from the previous settlement.

- Existing areas to retrain as APEA: productive areas for which there is a programme to improve facilities and environmental performance, aimed at achieving the characteristics and APEA requirements, on the basis of agreements or arrangements entered into among the organizations and the competent public bodies and businesses in the area, in accordance with State and regional regulations.

- $\quad$ APEA managed by municipal bodies: productive areas that are managed by only the government of a city but produce social and environmental benefits for nearby municipalities. The extension of these areas limits the dissemination of new small production areas and supports the redevelopment and relocation of existing areas.

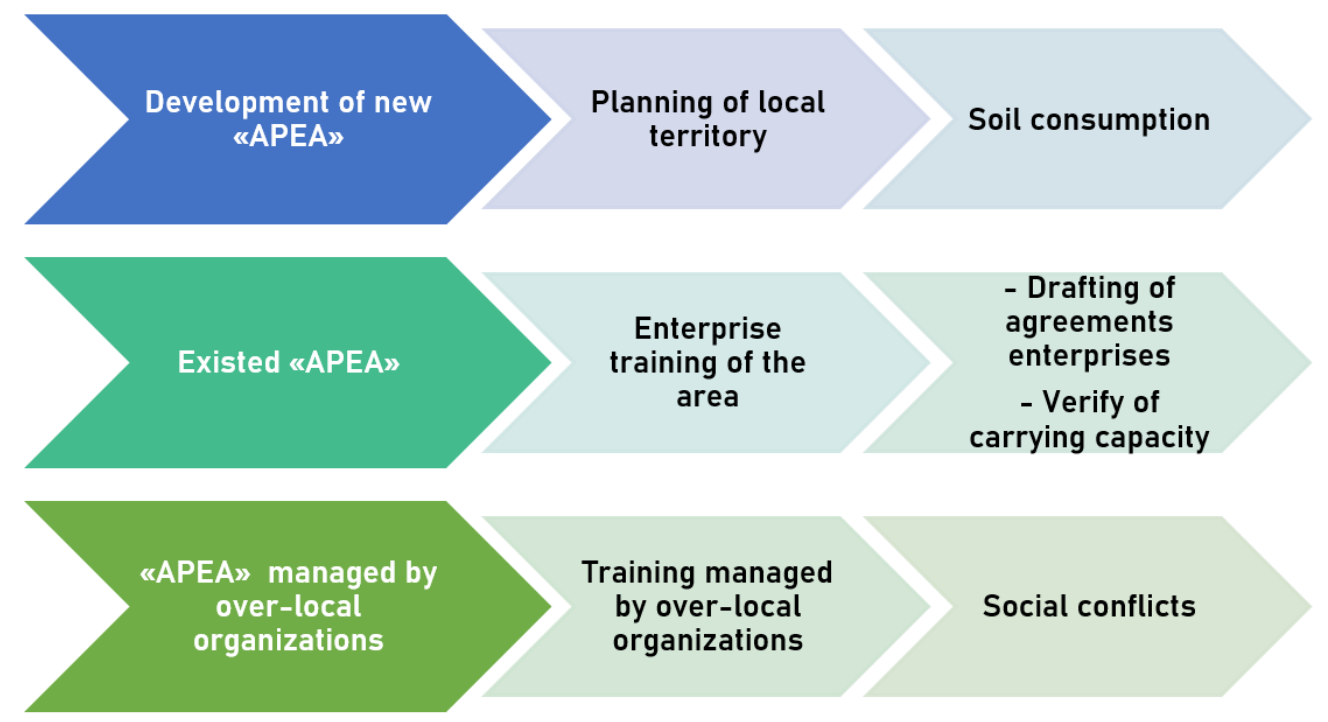

Figure 5. APEA types.

The realization of sustainable productive areas or the conversion and redevelopment of degraded productive areas improve the state of a territory. In particular, architectural and landscape quality is improved and production quality standards are increased. Moreover, this model of management facilitates the establishment of high-level innovative activities in terms of the specialization of productions and the reduction of environmental impacts on the territory. Therefore, these areas must be designed, manufactured, and maintained based on eco-efficiency. This implicates the guarantee of an integrated management system of the environmental, social, and economic aspects of a territory. The reducing and preventing of pollution of air, water, and soil, the protection of health and safety, and landscape and services improvement are some of these aspects.

Nevertheless, to date, there is an increasing consensus that the only way to ensure a sustainable growth is to decouple economic growth from resource use and pollution, namely an economy with the ability to grow without corresponding increase in pressures on the environment. Unfortunately, despite some progress made in this area, so far, no production area in Italy has achieved a sustainable economy where high resource productivity and high levels of social and human development of the territory are combined with low per capita resource consumption. Therefore, according to reports so far, it is a common assumption that there is a real delay in the process of developing APEA nationally, primarily for reasons of regulatory and bureaucratic complexity. 
This represents, in the current panorama of Italian industrial production capacity and efficiency, a serious gap for both material production (the lack of enforcement of land management innovation paths and areas) and immaterial production, for the lack of development and broadcast nationwide on specific know-how on the topic, and for new subjects to be able to effectively manage the areas [18].

However, considering the quantification and localization of Italian industrial production systems, we can assume a solution which represents the potential and gradual modification of Italian industrial districts, to promote local development through sustainable productive areas.

According to the latest Report of Intesa SanPaolo (2020) [42], Italian district enterprises in 2019, unlike previous years, registered moderate growth, showing an increase in turnover equal to $0.8 \%$.

The phenomenon of weakening of the national economic cycle, already visible at the end of 2018, intensified in the following months, mainly due to an increase in uncertainty on the international front, which led to a sharp slowdown in trade.

Even more so, the scenario for 2020-2021 will be profoundly affected by the dramatic consequences of the Coronavirus epidemic.

Despite this, many Italian industrial districts consist of companies able to grow at a sustained rate, create jobs, and show good levels of capitalization. Enterprises mostly of small-medium sizes are present.

From a sectoral point of view, there is a preponderance of companies from the Fashion Industry (about 30\%), Mechanics (19.5\%), and Metal Products (12\%). Following are two other sectors with strong district vocations such as Food and Beverage $(10 \%)$ and Furniture $(9 \%)$.

The sum of the first five sectors of specialisation represents $80 \%$ of the sample overall.

Moreover, based on economic, income, and asset performance, it is possible to identify the twenty best Italian industrial districts for the year 2019. The Mechanical Engineering districts (nine), which have been able to count on the following, are predominant on a still growing internal market (driven also by tax incentives) and good conditions of foreign demand. There are also six Agri-Food districts, three are in the Fashion industry and two of which are specialised in Rubber and Plastics. Geographically speaking, the Northwest (with seven districts) and, above all, the Northeast (nine), are led by Veneto with six district areas. The Centre follows with three districts and precedes Mezzogiorno, which has a district among the best twenty.

Many of these districts show a high presence of champion enterprises. The diffusion of champions is highest in the Northern regions-Lombardy (13.7\%), Piedmont (12\%), Veneto $(11.2 \%)$, and Trentino-Alto Adige (10.9\%) - between medium $(14.6 \%)$ and large (13.9\%) company dimensions, and in Mechanical Engineering (15.3\%). The success of these companies can be explained by evolved strategic positioning, even with the same sector and company size, being more active in international markets and showing a better propensity to patent.

This indicates that a productive sector prevails dominated by small and medium-sized enterprises, supported by big players, that can significantly affect the territory in terms of internationalization, innovation, and environmental and social sustainability.

Much more complex is the situation in central-southern Italy, where the number of industrial districts in the area is much lower than in the North of the country and very few champion enterprises were detected, which, however, could increase the economic capital of entire industrial districts. Therefore, it will be easier to revitalize the industrial districts of Northern Italy, which have high economic performance and which are more oriented to innovate management approaches using the principles of sustainability.

However, at the same time, the data also show an average size of industrial areas in the South of $25 \%$ above the national average and 30\% higher than that of the North, favouring the possibility of a progressive modification of industrial areas that could count on larger areas and therefore, be more interesting from the point of view of optimizing the 
processes involved, starting from the management of public services and energy supply and other production sources, production support services, and businesses [40].

\section{Proposed Methodology for the Implementation of APEA}

Sustainable development is a value system, on par with human rights, democracy, and freedom (and is closely interlinked with all these systems). Thus, sustainable development is essentially a strong ethical, or moral, pronouncement as to what should be done [43].

In the report, Our Common Future, it was argued that the environment does not exist as a sphere separate from human actions, ambitions, and needs.

The challenge of balancing economic development, the environment, and human health in the world is the driver for recent resource use and low-carbon development strategies that include the application of the Circular Economy concept. In this context, the relationship between industry and the environment is crucial for industrial business performance: environmental impacts have increased pressure on industrial businesses.

Environmental, social, and economic sustainability attracts the attention of customersconsumers that require greater transparency on the part of various industrial sectors. Should environmental and social aspects not be managed, this can involve a certain amount of risks for the companies that can negatively affect their reputation, their economic results, and the territory where they are located.

Companies are called to interpret global sustainability challenges, defining concrete and distinctive actions, taking the opportunities offered by greater attention to environmental and social aspects. In recent times, the concept of Corporate Social Responsibility (CSR) [44] has evolved into the concept of Global Corporate Citizenship (GCC) [45]. According to this vision, in addition to engaging in CSR logics, a company must also implement actions of community philanthropy, making its human and financial resources available to community projects inspired by principles of social entrepreneurship and corporate governance.

From this perspective, it is important to establish an excellent allocation of resources, especially financial ones. This is usually performed to carry out interventions designed according to the APEA model, which is capable of producing the highest environmental, economic, and social repercussions in the territorial context of reference.

To this end, the use of multi-criteria assessment techniques-capable of taking into account multi-dimensional aspects relating to the same type of work, both in the programming and management phases of the individual initiatives to be implemented and multi-dimensional aspects relating to the same type of work-appears to be useful both in the case of the construction of a new production plant and when it comes to redeveloping an entire industrial district in a state of complete and/or partial abandon [46,47].

Depending on the productive sector of interest and available data, it is possible to use different assessment tools that can express the multi-dimensional nature of initiatives related to the redevelopment of the territory according to the APEA model.

By resorting to the operations research optimization algorithms [48], it is possible to resolve decision-making problems regarding the selection of the site on which to carry out interventions that include actions to transform industrial areas into APEA using multiple evaluation criteria, able to consider both the morphological characteristics and socioeconomic characteristics of the area, through the construction of functional relationships between variables.

To pursue the objectives deriving from interventions carried out according to principles of eco-efficiency, the problem arises of selecting, among some areas to be redeveloped, those most suitable to be transformed through actions of this type. Each area is assessed by identifying certain criteria defined according to the objective attributable to the target to be reached.

In consideration of the investment cost of the project carried out in the $i$-th area and of the budget available, which defines the financial constraint characterizing the system, a mathematical model is written in the terms proposed by Linear Programming. 
The use of Operations Research techniques and tools allows the structuring of optimization models aimed at solving specific evaluation questions by defining an objective function and identifying one or more constraint conditions of various kinds.

The expressions of the logical-mathematical model referring to the decisional problem posed are constructed based on the linearity principle of Linear Programming, which is useful to support the selection process between design alternatives aimed at redevelopment of the urban industrial territory [49-51], in addition to using Geographic Information Systems [52]. Since, in the first instance, each design alternative must be evaluated in its entirety to establish whether to carry it out or whether to exclude it, the algorithms of Discrete Linear Programming (DLP) are used. DLP makes it possible to solve both cases of selection between urban areas that are better suited to be redeveloped with forestation [51], as well as related cases. For example, the composition of the best portfolio of investment projects is evaluated by employing urban sustainability criteria [50].

In general, models of linear programming can be implemented through specific mathematical programming tools, such as MATLAB, A Mathematical Programming Language (AMPL), Excel, Lingo, and Lindo. The selection of the type of software to be used is a function of the number of parameters and the number of win-win conditions that characterise the evaluation problem to be solved.

In this case, we proceed in the resolution of choice cases between investment projects and/or areas within urbanized industrial fabrics to be redeveloped through integrated intervention programs, as well as for the optimal selection of areas to be allocated to projects that respect the eco-functional logic at the base of APEA, the object of the present study. Therefore, the logical-mathematical models to be used are considered to be characterized by the integer constraint placed on the decision variables and resolved through the algorithms of Discrete Linear Programming (PLD).

Among the most used are those of dynamic programming, of implicit enumeration (such as Branch and Bound), algorithms of cutting planes, and the Brunch and Cut algorithm [53]. The model proposed for the selection of the site on which to implement transformation actions of industrial areas in APEA can be implemented through the software A Mathematical Programming Language (AMPL).

AMPL software corresponds to a mathematical language used to describe and solve optimisation problems [54], particularly those of scheduling problems [55]. This language is well suited to the modelling of decision-making cases related to urban industrial regeneration projects according to eco-system logics $[50,56]$.

Theoretically, in the present study, to pursue the $m$ objectives deriving from interventions carried out because of the eco-functional principles of the APEA, the problem arises of selecting, among the $n$ industrial areas to be redeveloped, those most suitable to be transformed through sustainability actions. Each area-assumed as variable $X_{i}$ of the problem-is evaluated since $k$ evaluation criteria are defined according to the objective attributable to the $m$-th target to be reached. In consideration of the investment $\operatorname{cost} C_{i}$ of the project carried out on the $i$-th area and of the budget available, which define the financial constraint characterizing the system, a logical-mathematical approach proposed by Discrete Linear Programming can be written as:

$$
X_{i j}=f\left(C_{i}, K, K_{j}\right)
$$

where:

$X_{i}=$ Area $(i=1, \ldots, n)$;

$C_{i}=$ Costs;

$K$ = Budget;

$K_{j}=$ Evaluation criteria $(j=1, \ldots, m)$.

Therefore, the mathematical logic approach considered by means of AMPL software will be able to support the implementation of the APEA model through some fundamental steps, such as: identifying the elements of the problem (specific objectives in relation to 
the targets, number of areas, evaluation criteria) as a set; specifying the parameters of the problem (budget, costs, multi-criteria evaluation matrix) to be inserted in the system; defining the value of the variables ( $\operatorname{var} X$ binary); structuring the objective function as a linear algebraic expression that maximises the capacity to pursue the multiple aims of the sustainable development initiatives of the urban industrial areas; specifying the constraints of the problem to be solved.

In light of this, it can be stated that a multi-criteria evaluation model, specifically the logical-mathematical approach proposed through Discrete Linear Programming, allows support of the identification of urban productive areas to be converted into APEAs and the selection of more sustainable performance from an economic, environmental, and social point of view, promoting the development of a territory.

\section{Conclusions}

Anthropic action, in recent years, has determined and continues to determine innumerable impacts on the environment and, therefore, on the territory, creating potential environmental and social damage in more and more extended areas that at this point, concern all of the planet and that, in the long term, can cause impoverishing of environmental resources and the eco-systemic functions linked to them, with resulting important economic damage.

It is impossible to think that the population would grow as in the last century, during which world population has increased four times more than in the past, as well as the use of economic products that has increased forty times, the use of fossil fuels that has increased sixteen times, fishing that has increased thirty five times, and water use that has increased nine times more than in the past [57].

Therefore, it has been strongly spread within public opinion, in the last few decades, that human activities change the surrounding environment, creating air, water, and soil pollution and influencing the health of the population and its prospects of future development.

For this reason, it is necessary to adopt tools, standards, models, and procedures of industrial sustainability, shared both from public players and private ones present in the territory, to address enterprises towards a real sustainability path for the creation of a territory system.

Territory development can also be realised through APEA, which maximize positive externalities and minimize the negative ones produced by territory systems.

APEA implementation, both those that are new and those that revitalize and reorganize existing industrial areas, allow many benefits to be obtained. In particular, these benefits are: increased efficiency of input resources or environmental output production; maximized economic performances linked to better management of social and environmental performances. Moreover, the APEA model allows: a unitary management of economic productive services, increasing efficiency and reducing costs; realisation of environmental infrastructures through the use of the best available techniques; collective management of technologic spaces and systems at the service of the area; synergy creation among productive units present in the area, that allow activation of new services; the possibility to adopt the fulfilment of administrative simplifications to environmental and security rules; the increase in competitive territorial areas through innovative solutions, research and development services, environmental quality and green marketing improvement.

Nevertheless, currently, in Italy, extensive studies and analyses on this point of view have not yet been completed; least of all, there are arguments on how to set up a system, inside national and/or regional programmatic frameworks, and combine these projects with others that have different purposes.

Thus, criticalities observed concerning potential modification of Italian industrial areas in APEA are numerous. Regions have, in some way, independently legislated on the topic of APEA, without being able to reproduce the national guidelines or indications 
that permit the construction of a unique and coherent scenario of industrial development. Therefore, there is no national vision towards which productive areas should tend.

Further criticism is that there is no database that permits information regarding APEA to be inputted into a system, which is currently the case in Italy. However, some regions and provinces have proceeded in the development of an observatory and illustrated volume that collects the data, information, and performance of their own productive areas but there is, again, no organisation and standardisation of information at the national level that permits a quick exchange of these among workers in the sector.

At the municipal level, many productive areas have realised infrastructures that characterise productive areas and the services of enterprises mostly through the presence of a Consortium. However, these actions were not enough to proceed with a progressive modification of existing industrial areas in APEA.

In Italy, again, the training of subjects with specific skills regarding management of APEA is slow. These skillsets should be able to combine management with environmental and social aspects.

This highlights that it is necessary to realise new tools, processes, and standards that would be able to represent all the opportunities regarding the local-global, traditionalinnovation, economic sustainability-environmental, and social relationships that permit evaluation of the benefits of APEA and positive experiences to develop the Italian territory and industrial areas. Analytical tools permit specific areas to verify feasibility conditions, realisation, and the management of APEA initiatives. The individual enterprises should be able to understand the convenience of being located in an APEA and collaborate transversely among different areas to innovative products and processes through ecoinnovation logics.

For this reason, it is essential to adopt a logical-mathematical approach in order to implement the APEA model as presented in this study. Such a model, through the use of AMPL software, could solve some of the critical issues listed above-for example, the selection of existing urban industrial areas that should be allocated to APEAs for redevelopment from an economic and environmental point of view.

Therefore, the analysis shown constitutes a preliminary phase of the research activity aimed at assessing the effectiveness and efficiency deriving from the use of a logicalmathematical approach for the implementation of the APEA model.

Possible evolutions of the research could include the adoption of multi-criteria evaluation techniques to redevelop an urban industrial area in the south of Italy, in order to consider this reality as the first case study in which a logical-mathematical approach is used to develop better economic, environmental, and social performance in the whole territorial context of reference.

Author Contributions: M.R.S., data curation, investigation, writing—original draft preparation; B.E., conceptualization, writing - reviewing and editing; D.S., methodology, visualization, validation; O.M., resources, supervision, project administration. All authors have read and agreed to the published version of the manuscript.

Funding: This research did not receive any specific grant from funding agencies in the public, commercial, or not-for-profit sectors.

Institutional Review Board Statement: Not applicable.

Informed Consent Statement: Not applicable.

Data Availability Statement: Not applicable.

Conflicts of Interest: The authors declare no conflict of interest.

\section{References}

1. Barile, S.; Quattrociocchi, B.; Calabrese, M.; Iandolo, F. Sustainability and the Viable Systems Approach: Opportunities and Issues for the Governance of the Territory. Sustainability 2018, 10, 790. [CrossRef]

2. Elkington, J.; Fennell, S. Partners for sustainability. Greener Manag. Int. 1998, 24, 48-60. 
3. Barile, S. L'approccio sistemico vitale per lo sviluppo del territorio. Sinerg. Ital. J. Manag. 2011, 84, 47-87.

4. Proto, M.; Malandrino, O.; Supino, S. Sistemi e Strumenti di Gestione per la Qualità. In Percorsi Evolutivi e Approcci Manageriali; University of Salerno, Giappichelli Editore: Turin, Italy, 2008.

5. Proto, M.; Supino, S. Dal Management Ambientale alla Responsabilità Sociale delle Organizzazioni. In Stato del'arte e Dinamiche Evolutive; Giappichelli Editore: Turin, Italy, 2009.

6. European Commission. Communication from the Commission to the European Parliament, the Council, the European Economic and Social Committee and the Committee of the Regions. In Closing the Loop-An EU Action Plan for the Circular Economy; European Commission: Brussels, Belgium, 2015.

7. United Nations. Transforming Our World: The 2030 Agenda for Sustainable Development; United Nations General Assembly: New York, NY, USA, 2015.

8. European Commission. Communication from the Commission to the European Parliament, the Council, the European Economic and Social Committee and the Committee of the Regions. Biodiversity Strategy for 2030. In Bringing Nature Back into Our Lives; European Commission: Brussels, Belgium, 2020.

9. Schroeder, P.; Anggraeni, K.; Weber, U. The Relevance of Circular Economy Practices to the Sustainable Development Goals. J. Ind. Ecol. 2018, 23, 77-95. [CrossRef]

10. UNEP. The Global Outlook on SCP Policies. In Taking Action Together; UNEP: Nairobi, Kenya, 2012.

11. Yuan, Z.; Bi, J.; Moriguichi, Y. The circular economy: A new development strategy in China. J. Ind. Ecol. 2006, 10, 4-8. [CrossRef]

12. Lewandowski, M. Designing the business models for circular economy-Towards the conceptual framework. Sustainability 2016, 8, 43. [CrossRef]

13. Gower, R.; Schroeder, P. Virtuous Circle: How the Circular Economy Can Save Lives and Create Jobs in Low and Middle Income Countries; Tearfund and Institute of Development Studies: London, UK, 2016.

14. Ellen MacArthur Foundation. Delivering the Circular Economy: A Toolkit for Policymakers; Ellen MacArthur Foundation: Cowes, UK, 2015.

15. United Nations. Available online: https:/ /www.un.org/sustainabledevelopment/ (accessed on 30 November 2020).

16. Conticelli, E.; Tondelli, S. La Pianificazione delle Aree Produttive per lo Sviluppo Sostenibile del Territorio; Alinea Editore: Firenze, Italy, 2009; pp. 1-136.

17. Sessa, M.R.; Malandrino, O. The role of APEA for the development of a territory: Analysis of state of the art and prospects in Italy. In Proceedings of the 17th International Conference-INTI International Network of Territorial Intelligence-4th International Conference-ICSR Mediterranean Knowledge, Salerno, Italy, 23-24 October 2018; Gutenberg Editor: Fisciano, Italy, 2018.

18. Studio sull'Applicazione delle APEA e Linee Guida su APEA-EcoAP nelle Regioni Convergenza e nelle altre Regioni nell'ambito del Programma Operativo Nazionale "Governance e Azioni di Sistema", FSE 2007-2013, Aree Produttive Ecologicamente Attrezzate. Available online: http:/ / www.cresmeconsulting.it/wp-content/uploads/2015/07/apea_2012.pdf (accessed on 10 December 2020).

19. Tarantini, M.; Di Paolo, A.; Dominici, A.; Dell'Isola, M. Linee Guida per l'Insediamento e la Gestione di Aree Produttive Sostenibili. Available online: https://www.enea.it/it/seguici/pubblicazioni/pdf-volumi/2007/v07_11lineeguidasiam.pdf (accessed on 15 December 2020).

20. Korte, B.; Fonlupt, J.; Vygen, J. Optimisation Combinatoire: Theorie et Algorithms; Springer: Berlin, Germany, 2010.

21. Van Elegem, B.; Embo, T.; Lust, N. A methodology to select the best locations for new urban forests using multicriteria analysis. Forestry 2002, 75, 13-23. [CrossRef]

22. Wolfslehner, B.; Vacik, H.; Lexer, M.J. Application of the analytic network process in multicriteria analysis of sustainable forest management. For. Ecol. Manag. 2005, 207, 57-170. [CrossRef]

23. Guarini, M.R.; Nesticò, A.; Morano, P.; Sica, F. A Multicriteria Economic Analysis Model for Urban Forestry Projects. In International Symposium on New Metropolitan Perspectives; Springer: Cham, Switzerland, 2018; pp. 564-571.

24. Roy, B.; Vincke, P. Multicriteria analysis: Survey and new directions. Eur. J. Oper. Res. 1981, 8, 207-218. [CrossRef]

25. Cariani, R. Eco-Aree Produttive. In Guida All'eco-Innovazione, Alle Politiche per la Sostenibilità e ai Progetti Operativi Nelle Aree Produttive Ecologicamente Attrezzate (APEA); Ambiente Editore: Milano, Italy, 2013.

26. Beltramo, R.; Vesce, E.; Pairotti, M.B. L'area industriale di Pescarito: Introduzione allo studio. In Prove di APEA. Strumenti per l'Evoluzione Verso le Aree Produttive Ecologicamente Attrezzate. Il caso Pescarito; Beltramo, R., Vesce, E., Eds.; Ambiente Editore: Milano, Italy, 2014.

27. Merli, R.; Preziosi, M.; Acampora, A. How do scholars approach the circular economy? A systematic literature review. J. Clean. Prod. 2017, 178, 703-722. [CrossRef]

28. An International Framework for Eco-Industrial Parks. Available online: https:/ /openknowledge.worldbank.org/bitstream/ handle/10986/29110/122179-WP-PUBLIC-AnInternationalFrameworkforEcoIndustrialParks.pdf? sequence=1\&isAllowed=y (accessed on 20 December 2020).

29. Lowe, E.; Moran, D.H. A fieldbook for the development of eco-industrial parks. In Report for the U.S. Environmental Protection Agency; Indigo Development International: Oakland, CA, USA, 1995.

30. Lowe, E. Creating by-product resource exchanges: Strategies for eco-industrial parks. J. Clean. Prod. 1997, 5, 57-65. [CrossRef]

31. Ehrenfeld, J.; Gertler, N. Industrial ecology in practice: The evolution of interdependences at Kalundborg. J. Ind. Ecol. 1997, 1, 67-79. [CrossRef] 
32. Heeres, R.R.; Vermeulen, W.J.V.; De Walle, F.B. Eco-industrial park initiatives in the USA and the Netherlands: First lessons. J. Clean. Prod. 2004, 12, 985-995. [CrossRef]

33. Cutaia, L.; Morabito, R. Sostenibilità dei Sistemi Produttivi. In Strumenti e Tecnologie verso Lagreen Economy; ENEA: Roma, Italy, 2012; 352p.

34. ISPRA. Scenari di Impatto Ambientale Relative Alle Attività Produttive e Strumenti Economici volti all'Autosostenibilità di Sistema. In Strumenti Innovativi per una Crescita Economica Sostenibile; ISPRA Editore: Roma, Italy, 2015; Volume 1.

35. Ellen MacArthur Foundation. Towards the Circular Economy Vol.1: An Economic and Business Rationale for an Accelerated Transition; Ellen MacArthur Foundation: Cowes, UK, 2013.

36. Europe Sustainable Development Report. 2020. Available online: https://s3.amazonaws.com/sustainabledevelopment.report/ 2020/europe_sustainable_development_report_2020.pdf (accessed on 20 December 2020).

37. Roadmap for Localizing the SDGs: Implementation and Monitoring at Subnational Level. Available online: http:/ / docs.wixstatic. com/ugd/bfe783_49c2d8178d214bde9ec14154dd70e921.pdf (accessed on 20 December 2020).

38. Cavalli, L.; Farnia, L.; Vergalli, S. Verso la Sostenibilità: Uno Strumento a Servizio delle Regioni; Eni Enrico Mattei Foundation: Milan, Italy, 2019.

39. United Nations Economic and Social Council. From Global to Local: Supporting Sustainable and Resilient Societies in Urban and Rural Communities. Available online: https://sustainabledevelopment.un.org/content/documents/26614Written_Statements_ NGO.pdf (accessed on 20 December 2020).

40. Sessa, M.R.; Sica, N. C'è spazio per la bioeconomia. Nuova Energ. 2015, 2, 58-63.

41. Formez. Le aree Ecologicamente Attrezzate nella Legislazione Regionale. Available online: http://focus.formez.it/content/ areeecologicamente-attrezzate-legislazione-regionale (accessed on 20 December 2020).

42. Intesa SanPaolo. Economia e Finanza dei Distretti Industriali. Available online: https://group.intesasanpaolo.com/content/ $\mathrm{dam} /$ portalgroup/repository-documenti/research/it/economia-e-finanza-dei-distretti/12-Economia\%20e\%20finanza\%20 dei\%20distretti\%20industriali.pdf (accessed on 20 December 2020).

43. Holden, E. The Imperatives of Sustainable Development. Sustain. Dev. 2017, 25, 213-226. [CrossRef]

44. Elkington, J. Cannibals with Forks. In The Triple Bottom Line of 21st Century Business; Capstone Publishing Ltd.: Oxford, UK, 1997.

45. Schwab, K. Global Corporate Citizenship. Foreign Aff. 2008, 87, 107-117.

46. Guarini, M.R.; Morano, P.; Sica, F. Eco-system Services and Integrated Urban Planning. A Multi-criteria Assessment Framework for Ecosystem Urban Forestry Projects. In Values and Functions for Future Cities; Springer: Cham, Switzerland, 2018.

47. Guarini, M.R.; Morano, P.; Sica, F. Historical School Buildings. A Multi-Criteria Approach for Urban Sustainable Projects. Sustainability 2020, 12, 1076. [CrossRef]

48. Gilardino, A.; Rojasa, J.; Mattosa, H.; Larrea-Gallegos, G.; Vàzquez-Rowe, I. Combining operational research and Life Cycle Assessment to optimize municipal solid waste collection in a district in Lima (Peru). J. Clean. Prod. 2017, 156, 589-603. [CrossRef]

49. Chakhar, S.; Mousseau, V.; Pusceddu, C.; Roy, B. Decision map for spatial decision making in urban planning. In Proceedings of the 9th International Computers in Urban Planning and Urban Management Conference, London, UK, 29 June-1 July 2005 ; Batty, M., Ed.; The Centre for Advanced Spatial Analysis (CASA), University College: London, UK, 2005; pp. 1-18.

50. Nesticò, A.; Sica, F. The sustainability of urban renewal projects: A model for economic multi-criteria analysis. J. Prop. Invest. Financ. 2017, 35, 397-409. [CrossRef]

51. Nesticò, A.; Guarini, M.R.; Morano, P.; Sica, F. An Economic Analysis Algorithm for Urban Forestry Projects. Sustainability 2019, 11, 314. [CrossRef]

52. Shirabe, T. A model of contiguity for spatial unit allocation. Geogr. Anal. 2005, 37, 2-16. [CrossRef]

53. Ventura, P. Alcuni Contributi alla Separazione Primale e Duale per Problemi di Programmazione Lineare Intera; Serie 8; A-La Matematica nella Società e nella Cultura, 2; Unione Matematica Italiana: Bologna, Italy, 2003; Volume 6, pp. 335-338.

54. Schoen, F. Modelli di Ottimizzazione per le Decisioni; Società Editrice Esculapio: Bologna, Italy, 2006.

55. Dolan, E.; Moré, J.J. Benchmarking optimization software with performance profiles. Math. Program. 2002, 91, 201-213. [CrossRef]

56. Bagstad, K.J.; Semmens, D.J.; Waage, S.; Winthrop, R. A comparative assessment of decision-support tools for ecosystem services quantification and valuation. Ecosyst. Serv. 2013, 5, 27-39. [CrossRef]

57. Potočnik, J. Effective recycling policies advance Europe's Green Economy. In Proceedings of the Green Dot 2010: Green Economy in Action-5th International PRO EUROPE Congress, Brussels, Belgium, 7-8 October 2010. 